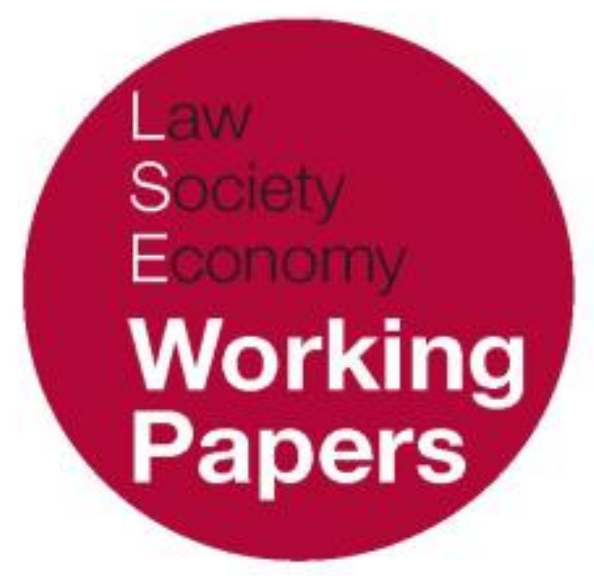

\title{
Perspectives on Liberalisation
}

\author{
Niamh Dunne
}

LSE Law, Society and Economy Working Papers 6/2017

London School of Economics and Political Science

Law Department

This paper can be downloaded without charge from LSE Law, Society and Economy Working Papers at: www.lse.ac.uk/collections/law/wps/wps.htm and the Social Sciences Research Network electronic library at: https://papers.ssrn.com/sol3/papers.cfm?abstract_id=2969826. (C) Niamh Dunne. Users may download and/or print one copy to facilitate their private study or for non-commercial research. Users may not engage in further distribution of this material or use it for any profit-making activities or any other form of commercial gain. 


\title{
Perspectives on Liberalisation
}

\author{
Niamh Dunne*
}

\begin{abstract}
A near-ubiquitous concept in legal debates on contemporary approaches to market regulation and reform, liberalisation broadly speaking involves a transition from controlled to competitive markets. Yet for many, liberalisation implies not merely practical processes and legal instruments of economic reorganisation and governance, but moreover a higher-level conception of how markets fit within society, and thus how law might be deployed to achieve wider social and economic goals. This article explores the concept of liberalisation in both its technical and more-disputed normative dimensions, seeking to situate the latter within an understanding of the functioning — and limitations — of the former.
\end{abstract}

* Assistant Professor, Department of Law, London School of Economics and Political Science. 


\section{A. INTRODUCTION}

It is a political imperative, pursued for itself... The policy is the policy because it is the policy. ${ }^{1}$

Embraced as indispensable to efficiency and growth by some, a bête noire in the vein of blind neoliberalism for others, economic liberalisation broadly speaking implies a transition from controlled to competitive markets. Yet for a term so pervasive within contemporary debates about market regulation and reform, relatively little attention has been directed towards the concept itself. Simply put, we frequently mean quite different things when we talk of 'liberalisation'. Such ambiguity goes beyond the technical task of designing institutions and processes for market governance, moreover, as liberalisation incorporates a strong normative dimension, reflecting implicit value judgments about the benefit of markets alongside optimal approaches to economic and even social ordering. This article explores the concept of liberalisation with respect to both its technical and moredisputed normative elements, seeking to situate the latter within an understanding of the functioning — and limitations - of the former.

Examples of liberalisation span a broad spectrum of economic activity. The UK's telecommunications incumbent, for instance, has been subject to successive waves of privatisation, market opening, and structural reorganisation from the mid1980s. The granting of cabotage rights over the Dublin-London air route similarly enabled a successful challenge to the existing duopoly of flag carriers, launched the business of what became Europe's largest low-cost carrier, and saw the city pair develop into the world's second busiest route. More complex instances pertain to the liberal professions, such as the transformation of legal services through reform of restrictions on entry and practice. The most divisive examples involve public services, where liberalisation implies the possibility of separating doctrine from institutional form. ${ }^{2}$

The near ubiquity of liberalisation in modern economies should not obscure its contentious nature. Opponents question the effectiveness of liberalising reforms in practice, while developments such as privatisation and marketisation challenge the balance of public and private power within society. Debates take a strikingly polarised form: from a vision of unliberalised markets as sacrificing consumer welfare to protect vested interests, whether public or private; to viewing liberalisation as a dogmatic enterprise that aims to introduce market forces at any cost and as an end itself ${ }^{3}$ - the 'commodification of everything'. ${ }^{4}$ Accurately or otherwise, for many the concept of liberalisation is inextricably linked to other so-called

\footnotetext{
1 The well-known rationalisation of privatisation/liberalisation of BT, quoted in Hodge, Privatisation. An International Review of Performance (2000), 24.

2 Prosser, The Limits of Competition Law (2005), 107.

3 Ibid, 123.

${ }^{4}$ Harvey, A Brief History of Neoliberalism (2005), 165.
} 
neoliberal phenomena such as globalisation, austerity and even authoritarian liberalism. ${ }^{5}$ For others, conversely, it is a baseline requirement for inclusion within the modern global market economy. ${ }^{6}$ A leading scholar thus characterised contemporary discourse as reflecting ' $a$ kind of "us and them" syndrome. 7

The task of this paper is not to resolve such-perhaps indeterminabledisputes, but instead to explore what we mean, or might mean, when we talk of liberalisation. The starting point is that the term exists on two distinct planes. ${ }^{8}$ Liberalisation is, first, a technical concept, describing processes of market restructuring and change. Yet liberalisation has a markedly normative dimension, reflecting views on the optimal operation of markets, and society beyond. Contemporary discourse is complicated by the fact that it is often unclear which dimension is invoked; or, where potentially both, the extent to which views on one colour approaches to the other. ${ }^{9}$ Although the practical task of liberalisation is welltraversed in economic literature, there is an absence of work that addresses the concept of liberalisation as such. A central aim of this paper is to consider how the first technical dimension may be reflected in the second more-disputed normative aspect, creating scope for critical thinking on the intersection of the political ideas and economic processes that liberalisation represents. The paper thus identifies and explores various ideological perspectives — some competing, some overlappingon the concept of liberalisation and what it is intended to achieve. In so doing, we draw on examples from a range of jurisdictions and market circumstances.

Our primary purpose is taxonomical: to identify, explain and critique the elements that feed into the understanding of liberalisation as it exists within contemporary regulatory discourse and practice. We do so primarily from a legal standpoint, given that liberalisation has functioned repeatedly as both prompt for and construct within law-making processes. Accordingly, while we discuss political ideologies, pursued through technical processes of economic policymaking, at its core these market-making or -shaping activities are mediated through law. ${ }^{10}$ Moreover, although liberalisation is not a settled legal term-of-art, it has significant

\footnotetext{
${ }^{5}$ See e.g. early references to liberalisation in Heller, “Authoritarian Liberalism?", republished in 21 European Law Journal 295 (2015).

${ }^{6}$ Clifton, Comín \& Díaz Fuentes, "Privatizing public enterprises in the European Union 1960-2002: ideological, pragmatic, inevitable?” 13 Journal of European Public Policy 736 (2006), 738.

7 Hodge (2000), 4.

${ }^{8}$ The suggestion is neither novel nor controversial: see e.g. Picciotto, "Liberalisation and Democratisation," 77 Law \& Contemporary Problems 157 (2014), 160-61.

${ }^{9}$ Foucault described this phenomenon as 'adherence to a type of governmentality'. The Birth of Biopolitics (1979) [2008 edition], 89.

${ }^{10}$ Making equivalent observations, see Singh Grewal \& Purdy, "Introduction: Law and Neoliberalism," 77 Law \& Contemporary Problems 1 (2014), 9, and Bauman, "Forward," 63 Law and Contemporary Problems 1 (2000), 10. On the relationship between politics, economics and law here, see Aman, "Deregulation in the United States" in Geradin (ed.) The Liberalisation of State Monopolies in the European Union and Beyond (2000), 304.
} 
presence within both substantive law and law-making procedures. ${ }^{11}$ Both processes and underlying policy objectives thus need to be cognisable in legal terms.

A more oblique purpose is to supplement existing evaluative frameworks for market intervention. By exposing the ideological assumptions that underpin liberalisation, it becomes possible to develop more nuanced metrics by which to measure the success of any effort. Yet the paper is not itself an ideological one in any positive sense insofar as this may imply principled arguments for or against liberalisation in the abstract. The available empirical evidence is hugely mixed as to when and why liberalisation generates benefits: in short, 'it depends,' varying with market circumstances and means utilised. Many reforms are pursued with laudable aims, ${ }^{12}$ and even critics acknowledge that liberalisation has delivered certain tangible benefits. ${ }^{13}$ Concerns persist, however, that liberalisation facilitates cronyism; increases inequality; leads, primarily, to the advantaging of rent-seeking financial investors; ${ }^{14}$ or negatively impacts dynamic efficiency. ${ }^{15}$ More fundamentally, the deeper question of why we favour or dispute liberalisation as such implies a particular conception of the good that lies outside the ambition of this work. The impossibility of presenting a wholly disinterested account of disputed normative phenomena such as liberalisation means that we necessarily engage with the merits of the underlying claims to an extent. Nonetheless, our aim is principally to investigate the higherlevel concerns that may prompt liberalisation efforts, rather than to advocate for or against such activity in the abstract.

The focus of this paper is liberalisation in the context of microeconomic reform, that is, expansion of market forces within the domestic economy, or, within the EU, the internal market. We thus borrow the notion of 'economic activity' from EU law, which focuses on the potential for competition at enterprise level. ${ }^{16}$ Notably, this does not require the current existence of a competitive market, thus encompassing, inter alia, public and monopoly provision. ${ }^{17}$ Conversely, although the term liberalisation is also deployed in the macroeconomic context, particularly regarding trade, its use and implications here lie outside the paper's scope. This decision is explained partly due to space, but also salience. Although trade and domestic liberalisation can go hand in hand, they remain functionally and conceptually distinct, as illustrated, for example, by their discrete existences within

\footnotetext{
11 Within EU law, the term is found in the foundational Treaties (Articles 58-60 TEU), secondary legislation (Article 1(2), Directive 2006/123/EC) and jurisprudence of the Union Courts (e.g. C-265/08 Federutility EU:C:2010:205, para.32).

12 Hodge (2000), 230.

13 Prosser (2005), 237

14 Florio, Network. Industries and Social Welfare: The Experiment that Reshuffled European Utilities (2013), 352-53.

15 Pollitt, "The Role of Policy in Energy Transitions: Lessons from the Energy Liberalisation Era," 50 Energy Policy 128 (2012), 128; and Krämer \& Schnurr, “A Unified Framework for Open Access Regulation of Telecommunications Infrastructure,” 38 Telecommunications Policy 1160 (2014).

16 C-41/90 Höfner EU:C:1991:161, para.21.

17 Opinion of AG Jacobs in C-67/96 Albany EU:C:1999:430, para.311.
} 
the (much-disputed) Washington Consensus. ${ }^{18}$ The circumscribed scope of our inquiry does not preclude the possibility, however, that the ideological currents considered may have broader resonance.

Finally, a caveat: although liberalisation is not a zero-sum game, typically there are winners and losers. ${ }^{19}$ The process of 'creative destruction' can wreak havoc on company profits, conditions or levels of employment, and even firm survival. Such losses may be justified on the utilitarian basis that the majority benefits overall, or the more individualistic basis that the claims of the so-called losers were illegitimate from the outset; but we must nonetheless acknowledge the potential negative consequences of liberalisation for some, even where we find greater good overall. The oftentimes ambiguous virtues of liberalisation inform more practically-oriented critiques, considered in the discussion below.

The article is structured as follows. Section B introduces liberalisation as a functional concept, exploring its practical manifestations as legal processes of market restructuring. Section $C$ considers the concept of liberalisation in more normative terms, introducing and assessing six higher-level rationales or 'perspectives' that may explain or motivate the policy choice to liberalise. Without being exchuastive in scope, these reflect the principal currents of contemporary liberalisation practice, and thus bring greater clarity to the notion that liberalisation can be an ideological phenomenom. Section D considers the implications of the ideas identified in preceding sections, and concludes.

\section{B. LIBERALISATION-A FUNCTIONAL CONCEPT}

To ground the normative analysis that follows in concrete legal and market phenomena, we begin by exploring liberalisation in its technical sense: that is, its manifestations in practice as processes and/or instruments of economic reorganisation. In this context, liberalisation is a concept frequently invoked yet rarely defined. Most work-whether approaching liberalisation from legal, economic or public policy-oriented perspectives - proceeds on the basis that there is some settled, readily cognisable, albeit implicit, understanding of the term, thus negating any threshold necessity to discuss its specific definition. It nonetheless remains worthwhile to consider the assumed meaning(s) precisely, not least because a survey of relevant literature reveals a spectrum of differing approaches. Our goal is to sketch these parameters.

\footnotetext{
${ }^{18}$ Serra, Spiegel \& Stiglitz, "Introduction" in Serra \& Stiglitz (eds.), The Washington Consensus Reconsidered (2008).

${ }_{19}$ Pelkmans \& Luchetta, Enjoying a Single Market for Network Industries? Notre Europea-Jacques Delors Institute, Studies \& Reports 95 (February 2013).
} 
Some existing ambiguity may stem from the nebulous nature of the word 'liberal'. ${ }^{20}$ The broadest definition of liberalisation offered by the Oxford English Dictionary puts liberal at its core, namely as: 'the action or process of liberalising; the fact of being liberalised or becoming liberal; an instance of this. ${ }^{21}$ Yet the values implicit in that term are not fixed, so it means quite different things in different circumstances or to different people. Invoked in a political context, liberal runs the gamut from right to left. In popular perception, a liberal parent might imply understanding or irresponsibility, realism or naïveté. While the OED identifies a distinct sense within economics as 'favouring or being characterised by unrestricted trade' - a definition with some but not full resonance below-it offers a plethora of alternative meanings, ${ }^{22}$ which complicate the understanding and implications of the term to the extent that liberalisation is a sociological concept as well as a technical one.

To avert this difficulty, and to avoid prejudging the normative assessment to follow, we consider liberalisation primarily in functional terms: that is, how it is effected in markets. ${ }^{23}$ A functional definition is appropriate because it captures the nature of liberalisation as a process of market recalibration. ${ }^{24}$ As noted, the OED defines liberalisation, generally, in inherently dynamic terms as an 'action or process'. 25 This is supplemented by a second, technical definition, which places a similar focus upon its dynamic nature: '[t]he removal or reduction of restrictions placed upon (a particular sphere of) economic activity; an instance of this.'26 This latter definition, which adheres closely to popular usage albeit at an abstract level, introduces an additional theme: that of liberalisation as a movement from organised approaches to market governance towards a greater embrace of open or competitive forces. Notably, this definition does not set up a dichotomy between state and market, but instead between controlled and free economic activity. We return to this distinction below.

Both themes-liberalisation as a process, and a shift from market control to competition - underlie other (succinct) definitions that have been advanced. Armstrong and Sappington define liberalisation as 'the transition to competitive market conditions' ${ }^{27}$ Newbery identifies it as the task of subjecting sectors or businesses to market forces. ${ }^{28}$ Other similar, and similarly brief, approaches include: 'restructuring, regulatory reform and the development of competitive markets,'29 'the creation or deepening of a

${ }^{20}$ See, generally, Harvey (2005), 50 .

21 OED Third Edition, November 2010.

${ }^{22}$ Including generous, ample-bodied, absence of prudence or decorum, unobstructed, broadly construed, tolerant, and pursuit of civil liberties or social reform.

23 Adopting a similar approach, see Pelkmans \& Luchetta (2013), 17.

${ }^{24}$ See Aman (2000), 264, describing policies towards liberalisation as 'a transition'.

25 OED Third Edition, November 2010.

26 Ibid.

27 Armstrong \& Sappington, "Regulation, Competition, and Liberalization," XLIV Journal of Economic Literature 325 (2006), 325.

${ }^{28}$ Newbery, "Privatisation and Liberalisation of Network Industries," 41 European Economic Review 357 (1996), 358.

${ }^{29}$ Karova, Liberalisation of Electricity Markets and Public Service Obligations in the Energy Community (2012), 4. 
competitive market,'30 or simply 'opening to competition'. ${ }^{31}$ By contrast, in his work on economic regulation, Decker rejects the term because of its 'ideological overtones'- a point explored below-, instead substituting the phrase 'restructuring policies' for markets. ${ }^{32}$

These high-level descriptions raise two interrelated issues. The first is the sort of market conditions that liberalisation aims to move from, and towards. While microeconomic theory posits two basic models of organisation, monopoly versus perfect competition, most real-world structures lies between these poles. Liberalisation implies that, initially, economic activity is constrained by certain obstacles to unencumbered competition. Such constraints go beyond the recognition that atomistic competition is unrealistic: in effect, liberalisation presupposes that there is more that can be done to open a sector to competition. ${ }^{33}$ Three principal obstacles are relevant: structural barriers, legal barriers, and nonmarket status.

The most obvious structural barrier is the presence of significant scale economies, or natural monopoly, where a single firm meets demand more efficiently than any combination of firms. ${ }^{34}$ Historically, such markets were serviced by single vertically-integrated, often state-owned providers. The disadvantages are wellknown: the need for strict (often politicised) regulation; inefficiency, due to an absence of market-discipline; and unresponsiveness to customers. ${ }^{35}$ Similar tendencies towards monopoly arise from network effects, whereby demand increases with consumption. ${ }^{36}$ Liberalisation aims at disaggregation of integrated markets, and introduction of competition into potentially competitive segments. Where a firm is publicly-owned, at least partial privatisation may be contemplated.

Others obstacles are legal in nature. Regulatory barriers reduce competition and efficiency by limiting participants or raising costs. ${ }^{37}$ State-imposed or -approved licencing requirements restrict entry or dictate aspects of product or service provision, whether on a quantitative or qualitative basis. Other controls-price regulation, or marketing restrictions-similarly have cost- or rent-creating effects. Often there are legitimate reasons to supervise entry or participation, from consumer protection to safety, moral hazard or environmental concerns. Liberalisation typically entails a loosening of these conditions, yet must contend with the underlying public interest justifications for the initial regulation.

\footnotetext{
30 Pollitt (2012), 129.

31 Geradin, "Introduction" in Geradin (ed.) The Liberalisation of State Monopolies in the European Union and Beyond (2000), xi.

32 Decker, Modern Economic Regulation (2015), 2, fn.2.

33 We exclude social and environmental regulation; whilst these constrain unencumbered competition, libertarian arguments for wholesale 'deregulation' are distinguishable from sector-specific liberalisation.

34 OECD, Restructuring Public Utilities for Competition (2001), 8.

35 Pelkmans \& Luchetta (2013), 8.

36 OECD (2001), 8.

${ }^{37}$ Copenhagen Economics, Regulation and Productivity in the Private Services Sectors, Background report for Danish Productivity Commission, May 2013.
} 
Most controversial is use of liberalisation as a synonym for 'marketisation' of public service provision. ${ }^{38}$ Economists—and policymakers—apply market theory, and thus extol the benefit of market forces, to a broader range of activities and actors than the average citizen might recognise as within the 'market' as such. We thus also talk about liberalisation when bringing into the sphere of the market activities that were, historically, considered to constitute inherently public and thus non-market functions.

The second key issue involves the processes by which liberalisation might be realised in the marketplace. It is at this juncture that law is almost inevitably called upon to provide expression to the liberalisation process and its outcomes. ${ }^{39}$ Yet one reason why any high-level definition of liberalisation is of limited utility is that the term covers a multitude of legal processes and instruments that impact the market in different ways. Broadly speaking, each serves to lower barriers to entry by additional economic actors or, more proactively, to encourage or assist entry. 40

A preliminary distinction must be drawn between two ideas of liberalisationone narrow, one broad ${ }^{41}$ — which each find traction in existing literature. ${ }^{42}$ The narrow interpretation includes only efforts that aim, specifically, at 'liberalising prices and access to markets which bad previously been restricted by legal and regulatory barriers'. ${ }^{33}$ The broad interpretation is a synonym for reform and restructuring of markets more generally: it refers to the shift 'from using public policy instruments, such as regulation or public ownership of enterprises, to a greater reliance on market mechanisms and incentives to pursue consumer welfare, industrial, regional and/or employment objectives.' 44 The former might be deemed a literal approach, including only mechanisms that have as their precise objective the removal of specific obstacles to competition. The latter is an essentially bolistic one, including all regulatory efforts to reorient a sector towards the competitive paradigm. In this work, we adopt a similarly broad approach, in part because it reflects ordinary usage of the term, in part because of the mutually reinforcing nature of the legal mechanisms that comprise the liberalisation toolbox.

Policies aimed directly at market opening are the clearest means to achieve liberalisation, and reflect its narrowest interpretation. ${ }^{45}$ These include removal of monopoly or special rights, and, where entry requires access to essential infrastructure, mandatory sharing obligations. If barriers are legal, reform of licencing conditions or some degree of deregulation is required. 46 Somewhat

\footnotetext{
38 Prosser (2005), 1-2.

${ }^{39}$ Hodge (2000), 227.

40 See, generally, Armstrong \& Sappington (2006).

${ }^{41}$ Discussing an equivalent debate within privatisation, see Hodge (2000), 14-15.

42 Adopting a narrow conception, see e.g. Clifton et al. (2006) and Florio (2013). Reflecting the broader conception, see e.g. Pollitt (2012); Levi-Faur, "The Politics of Liberalisation," 42 European Journal of Political Research 705 (2003); and Prosser (2005), 99.

43 Gönenç, Maher \& Nicoletti, "The Implementation and the Effects of Regulatory Reform: Past Experience and Current Issues,” OECD Economic Studies No. 32, 2001/I, pp.11-98 (2001), 12.

44 Ibid.

45 Pelkmans \& Luchetta (2013), 40.

46 Ibid, 17.
} 
paradoxically, however, liberalisation can result in greater quantities of regulation, particularly where the incumbent retains significant power. ${ }^{47}$ Thus, 'regulation-forcompetition' combines deregulation and reregulation. ${ }^{48}$ It differs from commandand-control approaches, however, seeking to increase incentives for efficiency while minimising the regulatory burden. ${ }^{49}$ Concepts like 'responsive regulation, ${ }^{50}$ 'better regulation, 51 and 'smart regulation' 52 abound. Regulators also grapple with noneconomic objectives - such as funding of public service obligations ${ }^{53}$ - and how pursuit of such goals can be accommodated within a competitive environment. ${ }^{54}$

Structural reorganisation-typically, vertical separation-offers a more oblique means of liberalisation. ${ }^{55}$ Reorganisation is appropriate where the integrated structure of the incumbent gives it the ability and incentive to restrict competition. The market is 'liberalised' insofar as possibilities for future competition are strengthened: reduction of behavioural barriers to entry, reduced need for regulatory oversight, and/or increased numbers of economic actors. Yet, where integration generates efficiencies, reorganisation may involve a trade-off between the benefits of increased competition and efficiency losses that follow separation. ${ }^{56}$

Privatisation is a particularly controversial element of any liberalisation agenda. It involves, most prominently, sale of public enterprises, but can also encompass a shift to private provision through contracting out with public funding. ${ }^{57}$ By exiting the market in which it is monopoly supplier, the State creates space, opportunity and incentives for private entry, governed by normal competitive forces; and, where accompanied by structural reorganisation and/or mandatory access rights, with potential for competition between competing suppliers. To succeed as liberalisation in practice, privatisation requires regulatory reform and market-opening ${ }^{58}$ - though the converse is not necessarily true. ${ }^{59}$

Finally, antitrust scrutiny can have liberalising effect, de facto or de jure. ${ }^{60}$ The mere existence of competition law facilitates liberalisation in some instances. Initial efforts to liberalise the German energy sector, for instance, took the form of removing a pre-existing antitrust exemption, ${ }^{61}$ while liberalisation of the Scottish

\footnotetext{
${ }^{47}$ Sauter, Public Services in EU Law (2014), 32.

48 Levi-Faur (2003), 708.

${ }^{49}$ Gönenç et al. (2001), 26.

50 Ayres \& Braithwaite, Responsive Regulation: Transcending the Deregulation Debate (1992).

51 Weatherill (ed.), Better Regulation (2007).

52 European Commission, Smart Regulation in the European Union COM(2010) 543.

53 Gönenç et al. (2001), 47-54.

54 Ibid, 26.

55 See extended discussion in OECD (2001).

56 Lafontaine \& Slade, "Vertical Integration and Firm Boundaries: The Evidence," 45 Journal of Economic Literature 629 (2007).

${ }^{57}$ Hodge (2000), 14.

58 Gönenç et al. (2001), 58.

${ }^{59}$ Florio (2013), 341.

60 Pelkmans \& Luchetta (2013), 18; Damjanovic, "The EU Market Rules as Social Market Rules: Why the EU can be a Social Market Actor," 50 CMLRev 1685 (2013), 1705; and Sauter (2014), especially chpt.4.

61 Von Danwitz, "Regulation and Liberalisation of the European Electricity Market-A German View," 27 Energy Law Journal 423.
} 
water industry was prompted by modernisation of UK competition law. ${ }^{62}$ Alternatively, competition enforcers may target efforts, instrumentally, to achieve equivalent outcomes, whether seeking to prompt, supplement or compensate for an absence of liberalisation in the sector concerned. The break-up of AT\&T is perhaps the most famous example of antitrust enforcement securing an outcome in line with liberalisation goals, ${ }^{63}$ while a strategic use of EU competition law is similarly a central, contentious aspect of efforts to develop the internal market. ${ }^{64}$

Accordingly, we reach an interim assessment of liberalisation in functional terms as a process of market reorientation or reorganisation towards the competitive paradigm, which may encompass structural, regulatory and/or ownership transformations. We now turn to the more subjective focus of this article: the intersection between, and use of, legal tools of market liberalisation to pursue distinct normative goals regarding economic and social ordering.

\section{NORMATIVE PERSPECTIVES ON LIBERALISATION}

From the standpoint of economic theory, the rationale for liberalisation is straightforward: 'competition provides stronger and less manipulable incentives to efficiency than regulation. ${ }^{6} 65$ The truism that increased competition generates increased consumer welfare and thus societal benefit is premised on the perceived superiority of competition in contradistinction to public or private control: greater efficiency, innovation and consumer choice, with reduced need for costly, potentially counterproductive regulation. ${ }^{66}$ Since, in theory, markets are a better steward of economic activity than governmental planning or private monopoly or oligopoly, the logic of liberalisation dictates that there should be 'more market' where possible. This viewpoint was underscored in the late twentieth century by failure of many centrally-planned economies. ${ }^{67}$

Despite the textbook case for liberalisation, however, at its core this is not a purely technical activity. Rarely has theory been translated into practice with such vigour; an assessment more remarkable given that liberalisation is often on the policy agenda in markets where the public interest considerations at stake are not purely economic. That is, such markets are 'special... because of the nature of the needs they satisfy,' and thus are part of the broader social fabric. ${ }^{6}$ Moreover, translating the theory of liberalisation into successful practice has proven less than straightforward:

${ }^{62}$ Sawkins, "The Introduction of Competition into the Scottish Water Industry," 20 Utilities Policy 22 (2012).

${ }^{63}$ US v AT\&T, 552 F.Supp.131 (DDC 1982).

${ }^{64}$ See, e.g. within the telecommunications sector, C-202/07 France Télécom EU:C:2009:214, C-280/08

Deutsche Telekom EU:C:2010:603 and C-295/12 Telefónica EU:C:2014:2062.

${ }^{65}$ Newbery (1996), 368.

${ }^{66}$ OECD (2001), 10

${ }^{67}$ Hodge (2000), 31.

${ }^{68}$ Florio (2013), 347. 
the empirical evidence is equivocal, while resulting market structures are more complex than anticipated. ${ }^{69}$

Since the choice to opt for liberalisation is neither inevitable nor indisputable, the decision to do so reflects not merely a textbook understanding of the optimal operation of markets (and, indeed, what constitutes a 'market'), but also a positive decision to enhance competition and market forces over the status quo. At its root the determination to liberalise reflects a community choice about organisation of society, and the respective roles for the public and private sectors. ${ }^{70}$ The motivation(s) underlying such a choice typically have some normative element. This notion-that liberalisation is, at least partly, an ideological phenomenon-is uncontroversial. ${ }^{71}$ Less well explored, however, are the meaning and implications of the normative dimension of liberalisation. We use the phrases 'normative' or 'ideological' here to denote deeper rationales for intervention that extend beyond the immediate circumstances of the (perceived) market failure. Instead, the underlying policy motivation is some higher-level understanding of the optimal structure and functioning of markets—and, beyond this, occasionally, of society more generally. Such normative or ideological perspectives may be manifested through various factors, including the political persuasion of policymakers, the discourse surrounding liberalisation, and the process of constructing consent for interventions.

It is not our contention, however, that all liberalisation is motivated solely by high-level normative goals, nor that any decision to liberalise is reducible to a single (or even primary) rationale. Liberalisation as policy prescription has been supported by both normative arguments regarding economic freedom and political liberty, and positive arguments regarding government failures and the pursuit of efficiency. ${ }^{72}$ The reasons why any strategy is adopted are often multifaceted, ${ }^{73}$ encompassing express and tacit objectives. The motivations for the Thatcherite liberalisation efforts of the 1980s, for instance, comprised an expansive and quixotic list including control of public-sector pay and weakening of public-sector unions, widening of share ownership, and contraction of perceived state dependency. ${ }^{74}$ The immediate prompt may, conversely, be pragmatic or circumstantial: for example, realising the value of public assets is the purpose of much of the privatisation and marketopening activity undertaken to resolve the European sovereign debt crisis. The notion of normative motivation must also be distinguished from the concrete objectives, stated or implicit, that a reform programme seeks to achieve. Although there can be considerable overlap, the latter provide specific market goals to be attained, and thus a direct explanation for discrete positive efforts. The underlying

\footnotetext{
${ }^{69}$ See fns.13-15 above.

${ }^{70}$ Hodge (2000), 245.

71 Arriving at similar assessment, see e.g. Newbery (1996), 359; Pollitt (2012), 135; and Decker (2015), 2.

${ }^{72}$ Levi-Faur (2003), 711

${ }^{73}$ Hodge (2000), 45.

${ }^{74}$ Gamble, "Privatisation, Thatcherism, and the British State," 16 Journal of Law \& Society 1 (1989), 11.
} 
normative rationale, by contrast, explains why these goals are desirable, and how this links to the chosen means of realisation. Ultimately, such concerns may be a more forceful driver of liberalisation than explicit policy objectives, to the point where the latter become mere 'statements of hope and assertion'. ${ }^{75}$ Our purpose is simply to explain how ideological goals can drive liberalisation, and to identify normative strands in existing practice.

The most pessimistic approach conceives of liberalisation as itself an ideology: the notion of 'liberalisation for liberalisation's sake'. ${ }^{76}$ Rejecting this almost nihilistic stance, we endeavour to take a more nuanced (though not necessarily more optimistic) approach, exploring six normative perspectives that may inform or prompt liberalisation processes. These perspectives, without being exhaustive in scope, reflect the key ideological currents discernible within contemporary regulatory practice, and thus shed greater light on the notion that liberalisation is or can be a normative phenomenon.

Our first four perspectives - namely, state market withdrawal, avoidance of inefficient regulation, barnessing of market forces, and consumer sovereignty —are grouped under the heading of 'neoliberal'. At the core of each lies the view that market forces, and the self-interested wealth-maximising choices of private actors, constitute the best means to order society, and particularly, economic activity. Markets stand in contradistinction to governmental ordering which, these perspectives declare, is variously inappropriate, ineffective, or sub-optimal. Thus, the least restrictive alternative — most market, least state— should be adopted wherever possible. ${ }^{77}$ Each accordingly draws upon well-established theories of neoclassical economics regarding the efficient functioning of competitive markets. The danger inherent in the term 'neoliberal'-potentially 'too vague or polemical for responsible use'78_is acknowledged. We use it, loosely, to denote concerns that reflect some variation on the theme of 'less state/more market' in economic governance. ${ }^{79}$ What distinguishes each is the emphasis placed within this shifting balance. An alternative is to describe this category as 'efficiency-focused,' insofar as each theory aims, wholly or partly, to maximise efficiency through greater use of or deference to the market mechanism: whether by avoiding inefficient economic activity or regulation by government, or maximising productive or allocative efficiency by making markets work more effectively.

Yet the pursuit of liberalisation does not always translate into a simple 'less state/more market' dichotomy. Two further bases can alternatively be advanced,

\footnotetext{
75 Hodge (2000), 21.

76 See e.g. Burbach, Nunez \& Kagaritsky, Globalization and its Discontents: The Rise of Postmodern Socialisms (1997), 124; to similar effect in the context of privatisation, see Hodge (2000), 20.

77 Bekkedal, “Article 106 TFEU is Dead. Long Live Article 106 TFEU!” in Szyszczak et al. (eds.) Developments in Services of General Interest (2011), 69.

78 Singh Grewal \& Purdy (2014), 2.

79 As Singh Grewal \& Purdy (2014) argue, '[n] eoliberal claims advance the market side of [the] contest in capitalist democracies between capitalist imperatives and democratic demands' (3), thus relating to 'the unstable boundary between state and market' (18).
} 
namely to combat market power and increase market participation. Both involve a 'participatory' understanding of how markets function and what liberalisation achieves, viewing the promised 'open markets' in largely instrumental terms: markets are pried open, not because undistorted competition is itself a good, but because an open marketplace enables attainment of other socially valuable objectives. These latter perspectives depart from the efficiency focus of the neoliberal theories insofar as they are compatible with inefficient participation that nevertheless furthers such objectives. Moreover, the participatory conceptions are not premised upon any opposition of state and market, which at least the first three neoliberal theories imply, and indeed, can be invoked to support efforts that attack aggregations of private rather than public power.

For each normative perspective, we set out its broad contours, describing its underlying premises. We explain how the ideological objective underlying each can be furthered through liberalisation, particularly how and to what extent the market opening process links to the basic ideology. To support our contention that normative concerns have informed, to a greater or lesser extent, much liberalisation activity in recent decades, we draw links to liberalisation in practice, identifying examples in which such influences are either explicit or might be inferred. Finally, consideration is given to the potential limitations of each, in practical and ideological terms.

\section{1. 'ROLLING BACK THE STATE'}

I.

First, liberalisation may provide a strategy of state market withdrawal, typically through privatisation of public enterprises, or contracting out of public services. This represents, in effect, a rejection of the State qua economic actor within the marketplace.

As described, privatisation functions as a technique of liberalisation by creating opportunity and incentives for private operators to enter the marketplace, replacing the former public provider. Yet the real focus of privatisation may be less on securing new entry, but instead on removing the state from the realm of economic activity. Implicit here is an ability to distinguish between two separate spheres of activity: public non-economic activity on the one hand; private economic activity on the other. The only appropriate role for the State is within the context of the first. Where, however, the State already operates within the ostensible private sphere-for example, through public ownership of utility providers-liberalisation provides a means to 'roll back the frontiers of the State,' as Thatcher put the task, by creating an exit strategy for the public provider. Continuity of service is ensured through new entry by private providers. Our first normative perspective is thus summed up in (later, Chancellor) Nigel Lawson's exhortation that: 'The 
Conservative Party has never believed that the business of government is the government of business.' 80

This raises two interlinked questions: first, where and how is the supposed line between public and private spheres to be drawn; and second, why is state activity in the latter so disfavoured? As the iterative waves of privatisation and contracting out in the UK demonstrate, the answer to the first question is a moving target: from clearly economic activities like provision of telecommunications, energy and railway services, to more equivocal tasks like operation of the postal service, prisons and hospitals. Even accepting that these activities might potentially be provided for remuneration by private enterprises - and so fall within the expansive definition of 'economic activity' under EU law ${ }^{81}$ - it requires a significant further leap to conclude that the state should accordingly have no role. That is, why does the fact that private actors can provide a service translate into the imperative that the state must refrain from doing so? The ideology of state market withdrawal thus relies upon two related assumptions: the basic inappropriateness of the state as market actor, contrasted with the presumed effectiveness of private enterprise in comparison.

One reason advanced to explain the increased levels of privatisation at the end of the twentieth century is the recognition that, particularly in public utility sectors, a (state-owned, typically) monopoly is no longer required. ${ }^{82}$ From this perspective, the fact that competition is increasingly possible facilitates, and may encourage, privatisation of the former public monopolist. Yet the mere possibility of competition does not alone explain its prevalence. Instead, privatisation as an end itself is closely associated with a broader libertarian agenda. ${ }^{83}$ In their work on privatisation in Europe, Clifton et al. describe how discourse in respect of public enterprise and service provision shifted from the 1970s, moving from a 'social contract' model premised upon positive state intervention towards a value-free markets-oriented approach: ${ }^{84}$

As a new rhetoric and credo in the market replaced the post-war faith in the state, there was an assumption within the dominant modes of thinking that a change of ownership from public to private status would release enterprises from the shackles of bureaucracy and lead them via the cold winds of market forces to economic efficiency. 85

The result was, as Hodge describes, a renewed cultural enthusiasm for private enterprise, in contradistinction to the perceived failings of the state. ${ }^{86}$ Perhaps the

${ }^{80}$ Quoted in Newbery (1996), 359 (emphasis added).

${ }^{81}$ See fn.16 above.

82 Bauman (2000), 8

83 Dorfman \& Harel, “Against Privatisation as Such,” 36 OJLS 400 (2016), 403

${ }^{84}$ Clifton, Comín \& Díaz Fuentes, Privatisation in the European Union (2003), 8-9.

85 Ibid, 1.

${ }^{86}$ Hodge (2000), 35; see also Gönenç et al. (2001), 56. 
most (in)famous example of this ideology in practice is the wholesale privatisation programme implemented by the Conservative Government in the UK in the 1980s and 1990s, a flavour of which was demonstrated in preceding paragraphs. ${ }^{87}$ Privatisation as a core pillar of economic policy has indeed been described as 'Thatcher's personal gift to the economic policy agenda of the world ${ }^{88}$ As this statement implies, however, privatisation has been more or less enthusiastically embraced as a tenet of contemporary economic policy in many economies worldwide, so that the past quarter century has witnessed a paradigm shift from public to private provision in core areas.

As political and social questions, privatisation and contracting out are hugely disputed: both in terms of effectiveness in practice, and, in broader constitutional terms, because of what they say about the nature of the state and society, and the citizen's relationship to both. These concerns point to the limitations of the underpinning rationale.

First, it is unclear whether private enterprise is more successful at performing 'economic' functions than a public provider would be. Existing evidence is disputed-one commentator suggests that it is possible to find robust data confirming any predetermined view of the merits or otherwise of privatisation. ${ }^{89}$ Yet, there is significant evidence that, while privatisation typically increases productive efficiency and profitability, ${ }^{90}$ it also results in higher prices for consumers, without any improvement in social performance. ${ }^{91}$ Moreover, privatisation often deepens social inequality, negatively impacting upon employees of privatised enterprises and vulnerable consumers, while benefiting executives and investors. ${ }^{92}$

Another paradox of privatisation, to the extent it intends to 'roll back the state,' is that it is often accompanied by swathes of regulation that seek to reorient the privatised market towards competition. ${ }^{93}$ In the UK, for instance, the ensuing market structures have been described as 'ordered competition' rather than a competitive order as such, ${ }^{94}$ resulting in the emergence of a distinct discipline of public service law. ${ }^{95}$ Thus the reality of privatisation may conflict with our second perspective on liberalisation, which demonstrates great scepticism of the state in its regulatory guise.

\footnotetext{
${ }^{87}$ Discussing 'ideology' in this context, see Clifton et al. (2006), 738-39.

${ }^{88}$ Williamson, "A Short History of the Washington Consensus," in Serra \& Stiglitz (eds.), The Washington Consensus Reconsidered (2008), 16.

${ }^{89}$ Hodge (2000), 155.

${ }^{90} \mathrm{Ibid}, 226$; Gönenç et al. (2001), 59.

${ }^{1}$ Hodge (2000), 226; also Growitsch \& Stonzik, "Ownership Unbundling of Natural Gas Transmission Networks: Empirical Evidence," 46 Journal of Regulatory Economics 207 (2014).

92 Hodge (2000), 227.

${ }^{93}$ Majone, "Paradoxes of Privatisation and Deregulation," 1 Journal of European Public Policy 53 (1994).

${ }^{94}$ Burton, "The Competitive Order or Ordered Competition? The 'UK Model' of Utilities Regulation in Theory and Practice," 75 Public Administration 157 (1997), 174.

95 Prosser, "Public Service Law: Privatisation's Unexpected Offspring," 63 Law \& Contemporary Problems 63 (2000).
} 
A final, more ideologically-charged, challenge contests the assumption that economic activity and state provision are inherently incompatible. At its highest level, Dorfman and Harel launched a fundamental critique of privatisation 'as such', attacking it as 'the transformation of our political system and public culture from ones characterised by robust shared responsibility and political engagement to ones characterised by fragmentation and sectarianism. ${ }^{96}$ Such resistance is similarly implicit in the strong and continuing public opposition to and dissatisfaction with privatisation, despite its widespread adoption. ${ }^{97}$ From this viewpoint, which rebuts our first perspective on the basis that public provision is not only legitimate but vital in some areas, we see shades of Harold Wilson's critique of privatisation as 'selling the family silver'.98

II.

Second, liberalisation may reflect scepticism about the effectiveness of the state as regulator, and thus a desire to 'free the market' from inefficient or ineffective regulation. Here, liberalisation functions as a synonym for deregulation. ${ }^{99}$ As with our first perspective, the second evinces strong doubts regarding the desirability of state involvement in the marketplace. Where the two diverge is the focus of criticism: whether the state plays a primary role as economic actor or residual one as market regulator. Our second perspective suggests that, even in the latter role, state involvement is suboptimal, thus providing a basis for replacing public supervision with the invisible supervisory hand of the market mechanism. In opening markets by removing state-imposed barriers to competition, liberalisation facilitates this transition.

The second perspective is thus in line with standard public choice prescriptions from political economy. Public choice adherents subscribe to the 'capture theory' of regulation: whereby the regulator is not a benign maximiser of social welfare, but instead a politically-motivated actor which engages in its own rent-seeking behaviour, and is prone to capture by regulated entities. ${ }^{100}$ Markets controlled by regulators are thus inherently less likely to achieve efficient outcomes than those under competition. Moreover, where regulators have discretion or there is uncertainty about the development of regulatory policy, 'hold-up' may occur, whereby firms refrain from pro-competitive investment for fear that gains will be expropriated by regulatory change. ${ }^{101}$ Together, these observations - that regulators reach less efficient outcomes than markets, and the presence or risk of regulation deters competitive behaviour-culminate in a prescription for liberalisation, as the lesser of evils.

\footnotetext{
96 Dorfman \& Harel (2016), 426.

97 Pollitt (2012), 133; Florio (2013), 245.

98 Hodge (2000), 8.

99 McGowan, "State Monopoly Liberalisation and the Consumer," in Geradin (ed.) The Liberalisation of State Monopolies in the European Union and Beyond (2000), 212.

100 See, generally, Gönenç et al. (2001), 60-73, and Hodge (2000), 36-38.

101 Gönenç et al. (2001), 60-73.
} 
The ideological underpinnings of public choice and the deregulation movement are beyond dispute. In setting out to debunk the flaws of the so-called public interest theory of regulation, it has been suggested that public choice scholars essentially created their own straw man against which to take aim. ${ }^{102}$ This points to the strong, absolutist even, ideological conviction at the heart of such theories: namely, an insistence that state regulatory activity is inherently flawed, regardless of its results in practice or the market situation that would exist in its absence. Deregulation is thus an end itself, rather than a means to achieve strong yet fair competition within liberalised markets. ${ }^{103}$

The influence of the public choice movement is seen vividly in the US, where 'antiregulatory politics' have long had traction. ${ }^{104}$ Although deregulation in earnest began in the 1970s, ${ }^{105}$ the 'anti-statist ideological stance' of the Reaganite era brought these ideas to particular prominence. ${ }^{106}$ Consistent with a worldview whereby ' $[t]$ he nine most terrifying words in the English language are, "I'm from the government and I'm here to belp",'107 Reagan's approach to domestic policymaking was renowned for its deregulatory insistence. ${ }^{108}$ Indeed, his highly symbolic first executive action, within a week in office, was to remove remaining federal price and allocation controls in the oil sector. ${ }^{109}$ This move has been mimicked by Trump, who introduced a strictly quantitative policy of mandatory federal deregulation, justified in loaded terms that directly equate regulatory obligations to, in effect, spending other people's money. ${ }^{110}$

Our first and second normative perspectives are, essentially, two sides of the same coin-scepticism regarding the state in the market—with each adapted to the economic circumstances in which it rose to prominence. Unlike in Europe, where public interest was secured through state ownership, in the US the regulatory model historically relied upon governmental restrictions and requirements applied to private entities. ${ }^{111}$ In this latter context, the task of 'rolling back the state' naturally focused on limiting its regulatory role. This is not to suggest, however, that the ideology of 'freeing the market' has been absent across the Atlantic. In tandem with privatisation, the Thatcher government sought to ease what were styled as 'burdens on business' by limiting ('to stem the flow') the quantity of new regulation enacted. ${ }^{112}$

\footnotetext{
102 Hantke-Domas, “The Public Interest Theory of Regulation: Non-Existence or Misinterpretation?” 15 European Journal of Law and Economics 165 (2003).

103 Aman (2000) 268.

104 Singh Grewal \& Purdy (2014), 1.

105 Aman (2000), 267.

106 Hodge (2000), 34

107 Williams, "Policy, Process and Power: Understanding American Bureaucracy," in Williams (ed.) Explaining American Politics (1990), 97.

108 Including deregulation of savings \& loan businesses, cable television, long-distance telephone services, aviation, trucking, interstate bus services and ocean shipping, plus abolition of prominent regulatory agencies.

${ }^{109}$ Executive Order 12287, Decontrol of Crude Oil and Refined Petroleum Products, 28 January, 1981.

110 Presidential Executive Order on Reducing Regulation and Controlling Regulatory Costs of 30 January 2017.

111 Aman (2000), 265.

112 White Paper, Lifting the Burden, Cmnd. 9571, HMSO, 1985, para.8.1.
} 
While New Labour focused initially on improving the quality rather than quantity of regulation adopted, in time it too rediscovered the language of regulation as 'burdens'.113 This reached its apotheosis under the Coalition government, which introduced an express requirement of 'one in, one out' for regulation, ${ }^{114}$ subsequently ratcheted up to 'one in, two out'.115 Such an approach to state intervention - viewed as inherently problematic, occasionally inescapable, but to be avoided to the greatest extent possible-manifests a clear ideological bent, and commitment to minimalist government.

The limitations of this perspective are thrown into sharpest relief by various crises that followed flawed deregulation efforts: from the savings and loan crisis in the US in the 1980s/90s, the collapse of the California energy market in 2000-1, to the global financial crisis from 2008 onwards. Simply put, advocates of 'freeing the market' tend to underestimate the extent to which unregulated markets might misbehave-even before distributional concerns are considered. As one leading scholar argues, public choice can thus be criticised on the dual bases that it is premised on 'a seriously incomplete and under-theorised understanding of regulatory government,' while its empirical predictions are not borne out by concrete evidence of how regulatory agencies operate or what they achieve. ${ }^{116}$ Even if it is possible to withdraw the state from the so-called private sphere, there may be more acute limits to 'rolling back' its public functions via liberalisation.

\section{EFFICIENCY MAXIMISATION}

III.

Our third 'neoliberal' perspective focuses more directly upon the value of competition. Accordingly, liberalisation might be pursued, primarily, to foster and deepen market forces, to better achieve the benefits of efficient markets. Here, the focus is not the shortcomings of the state as market participant, but instead the superiority of well-functioning markets as a tool for economic organisation. This perspective thus adheres closely to the textbook understanding of market competition, and as such is squarely located within the 'more market' camp.

Where existing levels of competition are suboptimal, liberalisation has an obvious role. Most immediately, this may involve removal of legal barriers to participation, or structural reorganisation to facilitate competition within potentially contestable segments. Privatisation is often central, not because of a revulsion with state enterprise, but rather in an effort to enhance the managerial incentives within

113 Baldwin, "Better Regulation: Tensions Aboard the Enterprise," in Weatherill (ed.), Better Regulation (2007), 28-29.

114 See e.g. HM Government, One-In, One-Out (OIOO) Methodology, July 2011

115 Department of Business, Innovation \& Skill, Better Regulation Framework. Manual. Practical Guidance for UK Government Officials, July 2013, paras.1.9.1-1.9.49.

116 Croley, Regulation and Public Interests: The Possibility of Good Regulatory Government (2008), 3. See also Hodge (2000), 37-38. 
public companies and increase competitive pressures faced.117 In the context of public services, 'marketisation' is presented as a means to achieve greater efficiency, affordability and choice. ${ }^{118}$ In the context of less developed economies, liberalisation provides an opportunity to expand markets, by, for example, increasing business confidence, encouraging domestic and international investment, and generating employment. ${ }^{119}$ At its most trenchant, this ideology may shade into so-called 'market fundamentalism,' that is, 'the belief that markets by themselves lead to economic efficiency, that economic policies should focus on efficiency, and that distributional concerns could and should be taken care of elsewhere in the political process.' 120

This viewpoint is represented forcefully in the influential, but also infamous, Washington Consensus: a policy prescription a of micro- and macro-economic reforms for effective development, focusing on privatisation, liberalisation and macro-stability. ${ }^{121}$ Itself the subject of much ideological controversy, ${ }^{122}$ the Washington Consensus at its crudest embraces liberalisation in its most obviously 'neoliberal' form, and is taken to represent 'a set of policies predicated upon a strong faithstronger than warranted either by economic theory or historical experience - in unfettered markets and aimed at reducing, or even minimising, the role of government.'123

Unsurprisingly, a potent criticism of this approach is a confusion of ends with means: namely, that the search for 'more markets' becomes a politically important goal in itself, rather than in furtherance of more nuanced or defensible social or economic objectives. ${ }^{124}$ The stunning growth in inequality in many of the developing nations that endeavoured to implement the prescriptions of the Washington Consensus, alongside the comparative success of other economiesparticularly in East Asia-which declined to implement its reforms, specifically in relation to industrial policy, stand as an uncomfortable reproach to the truism that markets are inevitably a better steward of societal welfare than government intervention. ${ }^{125}$ In an influential critique that contributed to development of a socalled 'post-Washington Consensus,' Rodrik distinguished between outright denial of mainstream economic principles and their misuse. Rejecting market fundamentalism in emphatic terms as an example of the latter, he argued that:

\footnotetext{
117 Gönenç et al. (2001), 56-58.

118 Davies et al., "Universal Service Obligations: Fulfilling New Generations of Services of General Economic Interest," in Szyszczak et al. (eds.) Developments in Services of General Interest (2011), 158.

${ }^{119}$ Hodge (2000), 24.

120 Stiglitz, "Is there a Post-Washington Consensus?" in Serra \& Stiglitz (eds.), The Washington Consensus Reconsidered (2008), 46.

${ }^{121}$ Serra et al. (2008), 3-4.

122 Williamson (2008), 14.

${ }^{123}$ Stiglitz (2008), 41

${ }_{124}$ Ibid, 48.

125 See contributions in Serra \& Stiglitz (2008).
} 
Neoliberalism is to neoclassical economics as astrology is to astronomy. In both cases, it takes a lot of blind faith to go from one to the other. ${ }^{126}$

A danger inherent in our third perspective is thus that it may follow a logical argument - that markets are, in theory, an efficient means to organise economic activity - to suboptimal, and quite illogical, conclusions. Since liberalisation, ultimately, affects real markets (and thus real people), its pursuit must be alive to the problem of 'second best,' which besets attempts to translate uncompromising theory into imperfect practice.

IV.

Our fourth perspective conceives of liberalisation as a means to create or enhance consumer choice, and therefore bolster consumer sovereignty. ${ }^{27}$ From this viewpoint, it is not merely economic actors in the sense of producers and suppliers which benefit from market participation; primarily, it is consumers who gain from engagement. The introduction or strengthening of competition is accordingly a means to drive innovation and other competitive forces, placing consumers in a stronger position to assert power over quality and price. ${ }^{128}$ This is encapsulated in the statutory duty of the UK's Competition and Market Authority (CMA), which must 'seek to promote competition... for the benefit of consumers."129 A more radical version links consumer sovereignty, not merely to the relationship between consumers and producers, but relationships between individual consumers. Reliance upon the market mechanism to guide consumer choice enhances equal treatment, insofar as goods are allocated to those who value them most, and citizens are responsible for the costs of their actions. ${ }^{130}$ In this interpretation, the sovereign consumer is a libertarian one. ${ }^{131}$

Liberalisation in all its guises is crucial to furthering consumer sovereignty from this perspective. Privatisation and contracting out take activities from the public to the private sphere, turning the passive citizen into an empowered consumer. Market opening, deregulation and structural reorganisation facilitate development of stronger competitive pressure, through removal of legal or structural market features which shield economic actors from the effective exercise of consumer sovereignty. These restructuring processes may be complemented by competition enforcement against firm behaviour that similarly harms consumer welfare.

Our third and fourth perspectives thus both rely upon the benefits seen as inherent in the competitive process. Both fall on the 'more markets' side of the

\footnotetext{
126 Rodrik, "After Neoliberalism, What?" Paper presented at the Alternatives to Neoliberalism Conference, 23-24 May 2002, available at: http://www.new-rules.org/storage/documents/afterneolib/rodrik.pdf, 2.

127 See, generally, Persky, "Consumer Sovereignty," 7 Journal of Economic Perspectives 183 (1993).

128 See, generally, McGowan (2000); and Davies et al. (2011), 160.

${ }^{129}$ Enterprise and Regulatory Reform Act 2013, s.25(3).

130 Prosser (2005), 28.

131 Ibid, 20.
} 
state/market dichotomy, and both are, essentially, 'efficiency-focused'. Yet each remains distinct insofar as they differ appreciably in the extent to which they determine the ultimate distribution of resources. Our third perspective is concerned with maximising total welfare, namely a combination of productive and allocative efficiency. It thus aligns with Chicago School thinking about the optimal focus of market governance, leaving distributional concerns to extra-market mechanisms such as taxation. The fourth perspective, by contrast, is premised upon some rebalancing of the benefits of the market process to advantage consumers, at the expense of the traditionally dominant producer. ${ }^{132}$ It suggests an emphasis on allocative efficiency over productive efficiency, namely getting the best deal for consumers. It thus requires that the market provide 'a fair share of the resulting benefits' 133 to consumers, whereas our third treats such considerations as beyond the purview of the market. To secure this, this perspective may tolerate greater levels of state involvement than preceding ideologies. ${ }^{134}$

We nonetheless continue to locate this viewpoint within the 'neoliberal' bracket insofar as its underlying vision of the benefits of open and competitive markets contrasts with more redistributive or solidarity-based conceptions of markets as, principally, 'servants of the state's values'. ${ }^{135}$ It is therefore vulnerable to critiques of liberalisation as involving the imposition of a market society model upon public life, whereby citizenship is reduced to mere consumption of economic benefits and rights. ${ }^{136} \mathrm{~A}$ market-based view of citizenship conflicts with one premised on social solidarity, whereby the state has an inherent responsibility to ensure equal treatment regardless of economic resources. ${ }^{137}$ Prosser thus argued against a consumerist vision of citizenship because 'we do not come to the market as equals,' meaning that this theory is essentially non-egalitarian. ${ }^{138}$ Greater emphasis on consumer sovereignty may enhance the absolute level of consumer choice with respect to goods or services; but, absent some redistributive mechanism outside the purview of the market, it does little to attenuate existing inequalities in the ability of consumers to participate. Increasing the extent and competitiveness of the marketplace through liberalisation accordingly only generates greater choice for those consumers with both resources and knowledge to participate.

An example of this inherent limitation is seen in the findings of the CMA's energy market investigation. Regulatory efforts in the liberalised UK energy sector have focused on increasing competition through enhanced consumer participation-and thus consumer pressure on incumbents. Yet the inquiry found that the most vulnerable consumers are also those least able to exert such pressure and reap consequent benefits, because they are tied to the most restrictive tariffs

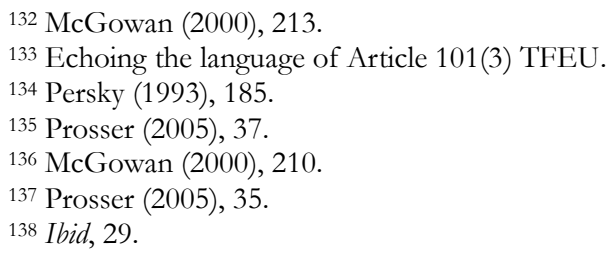


and have least knowledge and ability to exercise their rights (through switching etc.) ${ }^{139}$ In devising remedies, while one strand focuses on increasing levels of consumer sovereignty - 'helping customers to engage to exploit the benefits of competition'another acknowledges the intrinsic limits, and is concerned instead with 'protecting customers who are less able to engage to exploit the benefits of competition.'140

\section{MARKET PARTICIPATION}

V.

While, therefore, consumer sovereignty implies greater concern with the sharing of gains between enterprises and consumers than preceding perspectives, it is not primarily concerned with redistribution or other non-economic goals. To understand how liberalisation can nonetheless be relevant to the latter, we turn to an additional two normative perspectives which we describe as 'participatory'. Both view liberalisation as a means to secure open markets, in contradistinction to closed sectors where considerable power, public or private, might accrue. Contestability is key, whether as the means to an end (perspective five) or an end itself (perspective six). We consider these possibilities in turn.

Our fifth normative perspective views liberalisation, instrumentally, is as a means to combat private market power. As discussed in Section B, liberalisation is typically on the policy agenda within markets with structural or legal barriers to entry, which serve to protect existing market players. Here, absent effective competition, significant power might accrue to participants, whether due to monopoly, oligopoly or a de facto cartel. By facilitating entry which introduces countervailing competitive forces, liberalisation functions to control or reduce levels of private power amongst incumbents. In effect, the greater possibility for competition enables the breaking down, or competing away, of aggregations of power. From this perspective, liberalisation is a tool to prevent or lessen private capture, acting as a counterweight to socially-undesirable market power which might otherwise generate, amongst other outcomes, problematic levels of inequality.

The ultimate objective, accordingly, is to 'regulate' the functioning of the market and guide its outcomes through competition. Instead of the State 'picking winners,' new participants challenge the accrued power of incumbents. As Behrens explains, "the market" is, therefore, the opposite of an unregulated chaos where the law of the powerful prevails instead of the power of the law.'141 Whilst this perspective shares attributes with our third and fourth categories, the core focus is quite different: instead of pursuing the benefits of competitive markets, the aim is to harness the impact of the competition process to combat private accumulations of power. If neoliberalism

139 CMA, Energy Market Investigation. Final Report, 24 June 2016, paras.135-141.

140 Ibid, para.206.

141 Behrens, "The 'Consumer Choice' Paradigm in German Ordoliberalism and its Impact upon EU

Competition Law," Europa-Kolleg Hamburg Discussion Paper No.1/14, 5. 
is concerned with reconstructing the power of economic elites, ${ }^{142}$ this perspective, conversely, argues that the market process might break down such power. It thus brings to the forefront an inference inherent in the functional approach to liberalisation: if liberalisation represents a transition to competitive markets, merely removing barriers to competition is insufficient; successful liberalisation also requires entry and the emergence of competitive dynamics and discipline. These ideas are reflected eloquently in the work of Amato on the origins of antitrust, as a means to combat:

a crucial problem for democracy: the emergence from the company or firm, as an expression of the fundamental freedom of individuals, of the opposite phenomenon of private power; a power devoid of legitimation and dangerously capable of infringing not just the economic freedom of other private individuals, but also the balance of public decisions exposed to its domineering strength. ${ }^{143}$

Direct attacks on private power are uncommon within the discourse of liberalisation; perhaps because, for politicians and policymakers most concerned with distributional issues, liberalisation may seem a counterintuitive (or politically unpopular) solution. One may therefore query the extent to which this ideology has motivated liberalisation in practice, outside the realm of strategic antitrust enforcement to achieve liberalising objectives. ${ }^{144}$

Yet at least implicit within much liberalisation occurring within privatised markets is a desire to increase competitive forces to counterbalance the socially undesirable power of the status quo. This is seen, most clearly, in liberalisation efforts that follow flawed privatisation, whereby a public monopoly is translated into a more troubling private one. The telecommunications privatisations in the UK and Mexico provide notable examples. Here, subsequent efforts to introduce competition, alongside structural reorganisation of the vertically-integrated incumbent, can be seen as retrospective attempts to counter the immense private power created by privatisation. ${ }^{145}$ Moreover, while liberalisation of professional services has been justified primarily on a consumer sovereignty basis-namely, increased allocative efficiency-, by lowering barriers to entry and participation liberalisation can also tackle the socially-disadvantageous market power that accrues to incumbents. ${ }^{146}$ In terms of legal services, for instance, so-called 'unmet demand,' resulting from supra-competitive pricing by protected incumbents, can have far broader consequences in terms of access to justice and fairness within society that

\footnotetext{
142 Harvey (2005), 19.

143 Amato (1997), 2.

${ }^{144}$ For example, calling for 'reinvention' of contemporary antitrust to address the problem of 'superstar companies' in concentrated markets, see The Economist, "A giant problem," 17 September 2016.

145 See e.g. Clifton, The Politics of Telecommunications in Mexico (2000).

146 Canton, Ciriaci \& Solera, The Economic Impact of Professional Services Liberalisation, European Commission Economic Papers 533, September 2014.
} 
transcend the economic question of efficiency. ${ }^{147}$ Liberalisation functions to redress the balance.

Again, the CMA's energy investigation provides a neat example. To address its finding that the 'big six' suppliers were each able to exercise unilateral market power, ${ }^{148}$ the CMA made a series of recommendations to secure more effective competition specifically to challenge this existing power. These include reform of licensing requirements for retail suppliers, removing existing restrictions on differentiated offerings and innovative market behaviour. ${ }^{149}$ The investigation is notable, furthermore, insofar as it was motivated by public concern about the structure and functioning of-liberalised, but highly regulated - energy markets, particularly popular outrage regarding perceived undue power and consequent unfair behaviour. One option here would be to regulate more stringently; 150 the preferred approach of the CMA was to empower the market to fix itself.

VI.

Finally, a sixth approach views liberalisation primarily as a means to facilitate participation in liberalised sectors. The perspectives discussed thus far have focused upon how increased involvement makes the market work better, or improves resulting outcomes. Yet an alternative viewpoint is to consider the experience of new participants, and the benefits that they derive from opportunities to partake in and contribute to the competition process. Instead of fostering entry to achieve some subsequent goal, this perspective derives value from the very possibility of greater participation following liberalisation. Schweitzer, drawing parallels to the EU law concept of solidarity, sums up this viewpoint as: 'the principle that economic opportunities shall be open to all.'151

Such ideas are associated closely the school of thought known as ordoliberalism. ${ }^{152}$ Among other themes, this is held to support a 'right' for individuals to compete within the marketplace, free from political interference yet backstopped by strong state protection for open competition.153 From this perspective, economic freedom is closely linked to political freedom. Although the precise implications of ordoliberalism are disputed, ${ }^{154}$ this perspective is distinct

\footnotetext{
147 See, e.g., CMA, Legal Services Market Study. Interim Report, 8 July 2016, para.1.10.

148 CMA, Energy Market Investigation. Final Report, 24 June 2016, paras.156-160.

149 Ibid., paras.213-216.

150 Advocated before the 2015 General Election: The Guardian, "Ed Miliband targets energy firms with proposed price-cut powers for Ofgem," 13 March 2015.

151 Schweitzer, "Services of General Economic Interest: European Law's Impact on the Role of Markets and of Member States," in Cremona (ed.) Market Integration and Public Services in the European Union (2011), 58.

152 See, particularly, Gerber, Law and Competition in Twentieth Century Europe (1998), 232-65.

153 Sauter (2014), 112.

154 Contrast Gerber (1998), with Akman, "Searching for the Long-Lost Soul of Article 82EC," 29 OJLS 267 (2009) and Behrens, "The Ordoliberal Concept of 'Abuse' of a Dominant Position and its Impact on Article 102 TFEU," forthcoming in Nihoul/Takahashi, Abuse Regulation in Competition Law, Proceedings of the 10th ASCOL A Conference Tokyo 2015.
} 
from Chicago School approaches to the competitive process, which would generally support a positive right for competitors only where this increases efficiency. Liberalisation, from this perspective, aligns with ordoliberal thinking insofar as it applies state power to unlock or reinforce the marketplace, realising individual economic freedom, yet without prejudging the competition process. ${ }^{155}$ Under this viewpoint, strengthening individual economic rights is a task of general interest. ${ }^{156}$

Our participatory understandings of liberalisation overlap insofar as both emphasise market pluralism, secured by opening sectors to competitive forces. ${ }^{157}$ Where they diverge is in terms of the ultimate reason for participation: whereas the ordoliberal conception of plurality stresses the right of (even inefficient) economic actors to compete as a value in itself-what Foucault characterised as competition as essence $e^{158}$ - , the market power perspective treats competition instrumentally as the counterbalance to a less desirable alternative. Furthermore, while there are thosenotably Foucault himself ${ }^{159}$ - who treat ordoliberalism as a form of neoliberalism, this viewpoint remains distinct from the first four rationales considered. Not only can ordoliberalism be distinguished from contemporary understandings of neoliberalism insofar as it theorises the state as an instrument to enforce market processes, independent of democratic legitimation if necessary; 160 additionally, Foucault's critique was formulated before the great majority of contemporary liberalisation occurred. The outer boundaries of what conceivably falls within the category of liberalisation today are, for better or worse, much more expansive; the 'radical economic state'161 a starker construct. There is obvious complementarity with our fourth perspectives, consumer sovereignty, insofar as each prioritises an element of the interaction between consumption and production that underlies any market: consumers on the one hand, economic actors on the other. Yet this final perspective turns the orthodox understanding of markets - that production is about means and consumption about ends ${ }^{162}$ - on its head. From this viewpoint, the opportunity to participate is an end itself.

Ordoliberalism is afforded a central role in the perceived intellectual underpinnings of market governance within the EU. ${ }^{163}$ Securing 'market access' for potential competitors is, correspondingly, the lynchpin of liberalisation, whether through negative or positive integration. The fundamental freedoms have been applied to attack, inter alia, domestic measures that entrench public ownership, ${ }^{164}$ protect monopoly rights ${ }^{165}$ or limit basic parameters of enterprise freedom like

\footnotetext{
155 Sauter (2014), 34-35.

${ }_{156}$ Schweitzer (2011), 50-51.

${ }^{157}$ See, generally, Amato (1997), 14.

${ }^{158}$ Foucault (1979), 120.

159 Foucault (1979).

160 Singh Grewal \& Purdy (2014), 8.

${ }^{161}$ Foucault (1979), 86.

162 Discussed by Persky (1993), 187.

163 Gerber (1998).

164 C-105/12 Essent NV EU:C:2013:242.

165 C-456/10 ANETT EU:C:2012:241.
} 
pricing, ${ }^{166}$ all on the basis that such regulation hinders access to national components of the single market. Competition law, similarly, prohibits not only behaviour that diminishes consumer welfare, but also harms 'the structure of the market and, in doing so, competition as such, ${ }^{167}$ thus implicitly endorsing the notion that participation itself is valuable. Positive liberalisation efforts-adopted across a diverse range of activities including telecommunications, energy, transport, and services-typically require removal of any monopoly or special rights granted to incumbents, thus ensuring that markets are open to future competition. Where structural conflicts of interest exist, which may facilitate exclusion of new entrants by established players, some degree of market reorganisation may be mandated. Yet an irony for those who critique EU liberalisation as a 'neoliberal' phenomenon is that such efforts can, in fact, generate considerable inefficiency, ${ }^{168}$ while the viability of future competition appears to be less important than its potentiality. ${ }^{169}$ Thus, the focus of the liberalisation agenda is squarely upon building a distinct 'European market' within which participation is prioritised. ${ }^{170}$

Beyond its apparent tolerance for inefficiency, a final contrasting objection may be levelled against this ideology. Specifically, the impact of ordoliberalism has been identified in a critical tension between EU and (some) Member State preferences with respect to liberalisation: namely, that the latter work on the assumption that broader general interest is better served by collective 'public' approaches to market activity and governance, rather than strengthening of (selfinterested) private individual rights. ${ }^{171}$ While our final perspective is far from the extreme of market fundamentalism, it nonetheless finds inherent value in the market by virtue of the importance of participation. Such a perspective is fundamentally at odds with any viewpoint that rejects the market per se, and remains difficult to reconcile with critiques of the shortcomings of the market mechanism and its outcomes in practice. For better or worse, any normative argument for liberalisation as such has at its core a concomitant preference for markets as the basis for economic — and hence, social—organisation.

\footnotetext{
166 C-148/15 Deutsche Parkinson Vereinigung EU:C:2016:776.

167 C-501/06 P etc. GlaxoSmithKline v Commission EU:C:2009:610, para.63.

168 See e.g. Mizutani \& Uranishi, "Does Vertical Separation Reduce Cost? An empirical Analysis of the Rail Industry in European and East Asian OECD Countries," 43 Journal of Regulatory Economics 31 (2013); and Gugler, Libensteiner \& Schmitt, "Vertical Disintegration in the European Electricity Sector:

Empirical Evidence on Lost Synergies," Department of Economics Working Paper Series 190, WU Vienna University of Economics and Business, October 2014.

${ }^{169}$ See, e.g., discussion of the failures of the liberalisation regime for postal services in Wik-Consult, Main Developments in the Postal Service (2010-2013). Study for the European Commission, August 2013.

170 See, generally, Glachant \& Ruester, “The EU Internal Electricity Market: Done Forever?” 31 Utilities Policy 221 (2014), 222.

171 Schweitzer (2011), 50-51.
} 


\section{CONCLUSIONS}

This paper has sought to delineate and develop our understanding of the pervasive, yet vague, concept of liberalisation. The task is complicated by the intricate nature of its underlying premises: for many, liberalisation implies not merely a practical process of market reform, but moreover a higher-level vision of how markets fit within society. Debates surrounding liberalisation are, consequently, often formulated in the most forthright of terms, as in van Miert's vivid juxtaposition of sclerotic and inefficient state intervention against a dogmatic 'liberalisation macbine'.172 Yet it is difficult to disagree with Bekkedal's plea for moderation on the basis that 'the vision of the legal system is somewhat more sophisticated than to establish as much competition as possible."173

Just as there can be no successful 'one-size-fits-all' strategy for liberalisation policies, ${ }^{174}$ so too is there no single reason why liberalisation does or should—or should not-occur. As considered in Section C, a distinction can be drawn between concrete objectives and underlying ideology. Implicitly, any policy choice to liberalise involves two levels of decision-making: first, a technical choice relating to the optimal regulatory means to achieve the market outcome desired; and second, a higher-level choice proactively to alter the existing balance between public power, private power and some 'essential' notion of competition and the market mechanism within a wider social context. The contribution of this work has focused on the latter, exploring the potential normative currents that may underlie and inform liberalisation efforts. From the outset, our purpose has been primarily taxonomical: to identify and explain both the technical processes and potential ideological concerns - and, beyond, their interrelationship-which constitute the concept of liberalisation. Moreover, the normative perspectives discussed here are not claimed to be exhaustive in scope; instead, this paper reflects simply a first attempt to give greater content and clarity to the oft-repeated claim that liberalisation is an ideologically-charged phenomenon.

Yet the potential implications of this assessment are greater than that of a simple mapping exercise. A clearer understanding of the normative goals that motivate any liberalising intervention permits a more nuanced assessment of its effects and thus its success. We cannot truly determine whether a market reform has been effective in its own terms unless and until we appreciate its underlying motivations, in addition to its verifiable market impacts. It may, of course, be queried whether those underlying normative goals are worthy of pursuit-but that is a political rather than a scientific objection. The perennially-disputed question of the success or otherwise of privatisation of the UK railways, for instance, is arguably only fully understood when normative goals are considered alongside the mass of

\footnotetext{
172 Van Miert, "L'Europe, vecteur de la liberalisation," Speech, Paris, 21 October 1996.

173 Bekkedal (2011), 82.

${ }^{174}$ Stiglitz (2008), 46.
} 
quantitative data that privatisation has and continues to generate. The claim is not that ideology legitimates policymaking, nor that acknowledging normative context makes the practical task of achieving reform more straightforward. It does, however, give us a more nuanced appreciation of what market processes are intended to achieve within a broader societal context, thus serving to bridge the gap between technical instruments of liberalisation and the expressions of political will that these ostensibly represent. The normative rationale behind any liberalisation effort indicates the vision of the relationship between market, consumers, businesses and state that is eventually envisaged; hence it provides a pivotal additional blueprint against which to assess realisation of any liberalisation project.

It is thus impossible, and arguably would be undesirable, to sever practice from underlying ideology in the context of liberalisation. While both practice and theory have been critiqued based on presumed allegiance to a neoliberal agenda, ${ }^{175}$ this article has sought to demonstrate that the issues at stake are more nuanced. Thus the limits of liberalisation comprise not only the limits of the market in philosophical terms-'what money can't buy ${ }^{176}$ — but also its limits, or perhaps limitations, in economic terms.

175 Generally, Harvey (2005)

176 Sandel, What Money Can't Buy. The Moral Limits of Markets (2013). 